\title{
Progeroid syndromes: probing the molecular basis of aging?
}

\author{
David Kipling, Richard G A Faragher
}

\begin{abstract}
A valid method of studying age related degenerative pathologies is to study human genetic diseases that appear to accelerate many, though not necessarily all, features of the aging process. Such diseases are described as progeroid syndromes because of their possible relevance to many aspects of aging and age related disease. This article describes the recent progress made at the cellular and molecular levels in understanding the pathogenesis of one of the best characterised of these disorders, Werner's syndrome. These observations are related to some of the less well characterised progeroid syndromes within the context of the cell senescence hypothesis of aging, a theory formulated to explain the aging of regenerative tissue in normal individuals. (F Clin Pathol: Mol Pathol 1997;50:234-241)
\end{abstract}

Keywords: progeroid syndromes; aging; Werner's syndrome

With the proportion of the elderly within the population increasing dramatically the effects of the aging process are already the major item of expenditure for the National Health Service and will become the major health care challenge of the next century. ${ }^{1}$ Aging is associated with a subset of diseases including potentially fatal cardiovascular disorders, diabetes, and neoplasms, and crippling conditions such as cataract, macular degeneration, and auditory impairment, which greatly reduce the quality of later life. Understanding the mechanisms of human aging may therefore give important insights into the pathogenesis of a range of age related diseases. It may also allow age related diseases to be attacked at their roots by disabling the aging process itself, such a preventive approach being attractive for more than simple economic reasons.

Pathology, Universit of Wales College of Medicine, Heath Park, Cardiff CF4 4XN, UK D Kipling

Ocular Research Group, Department of Pharmacy, University of Brighton, Brighton BN2 4GJ, UK R G A Faragher

Correspondence to: Dr Faragher; email: rgaf@brighton.ac.uk inevitable result of the optimisation of evolutionary fitness in animal populations. In this

\author{
(2)
}

model, aging occurs because insufficient physio- $\overline{\bar{n}}$ logical resources are allocated by the body too somatic repair and maintenance. This modelo thus rules out a central "clock" that controlss the process. Such a central programme would: require resources to operate and this very $\vec{\omega}$ process would compromise reproductive effi-o ciency. It should however be emphasised that the lack of a mechanistic aging programmeir does not indicate the lack of involvement of programmed mechanisms in aging (such asin development or tissue repair). Indeed, one ${ }^{A}$ such mechanism, the senescence of individuab human cells, has been proposed as a key proc- $\vec{A}$ ess in the age related failure of regenerative tissue $^{3}$ and will be discussed in detail later.

As an evolutionary side effect of millions of years of selection for reproductive success the $\overrightarrow{0}$ genetic basis of aging is potentially extremely broad. Estimates of the number of genes that may have a role in determining lifespan in Homo sapiens have ranged from several hundred to tens of thousands (upwards of $7 \%$ o the total human genome ${ }^{4}$ ). With such a highly $y_{\Omega}^{\circ}$ polygenic system, to suggest that any single mechanism or simple network of mechanisms is responsible for the aging of a whole organism is rather naive. Applying the same logic the identification of candidate genes involved in successful aging through the study of norma centenarian "survivor" populations, while po- $\frac{0}{3}$ tentially feasible is likely to prove an extremelyt complicated task. ${ }^{56}$ An alternative approach first articulated as a formal concept by George Martin, is the study of heritable genetic diseases that mimic some, but not all, theo features of the aging process, to gain insights. into how the aging process functions in normas individuals. The study of such progeroids syndromes (like premature senility) has the advantage that only a single gene is usuallyg involved in each case. This renders hypotheseos easier to frame and test and makes the potentia identification of the defective allele amenable $e^{\infty}$ to modern reverse genetics and gene mapping studies in a way that the study of polygenio traits is not. The disadvantage of studying pro? geroid syndromes is that they are essentialls phenocopies of normal aging rather than the genuine article, any observations must thus be evaluated within the context of theorie? designed to explain how normal aging oper⿳亠二口犬. ates. One such theory is the cell hypothesis of aging.

\section{Cell hypothesis of aging}

A priori the simplest question that can be asked regarding the operation of the aging process is 
whether the mechanism of aging functions at the level of the organism or of the cells that compose it. For the first half of this century it was generally believed, based on experiments conducted in the laboratory of the Nobel laureate Alexis Carrel, ${ }^{7}$ that individual cells were immortal once placed into culture and that the mechanism of the aging process thus represented a failure of the organisation rather than the component parts. However, in the 1960s a series of experiments by Hayflick and Moorehead $^{8}$ demonstrated that normal human fibroblasts would only proliferate for a fixed number of passages during which the population would double in number about 50 times. The number of "population doublings" a culture would undergo appeared to be fixed by a mechanism internal to the cells that composed it. This theory was based on experiments in which cells from populations with different growth abilities were cocultivated and on the observation that cryopreservation in liquid nitrogen did not cause the culture to "forget how old it was". ${ }^{10}$ After completing its quota of population doublings the culture would be entirely composed of cells in a non-dividing state, which Hayflick termed "senescence". Based in part on the observation that embryonic fibroblasts completed more population doublings than neonatal cells, Hayflick proposed that senescence was linked to the aging process. These observations have been confirmed by hundreds of reports involving every renewing or conditionally renewing normal mammalian cell type that has been subjected to rigorous investigation. In addition a number of observations has emerged that support Hayflick's original contention that cell senescence and aging are associated (table 1).

\section{How do cells become senescent?}

The original description of in vitro fibroblast growth formulated by Hayflick assumed that the cultures studied were composed of homogeneous populations of cells that were either all growing or all senescent and that the failure to grow was a result of cell death. Both these assumptions, while initially sensible, were rapidly shown to be incorrect. Early work on RNA synthesis in growing and senescent fibroblasts showed that tritiated uridine incorporation occurred in the cells regardless of age, ${ }^{25}$ senescent fibroblasts were thus alive and metabolically active. Subsequent pulse labelling experiments performed at every passage with tritiated thymidine and designed to pick up viable cells that never divided showed that unlabelled cells were present in very young cultures and that labelled cells were present in very old cultures. $^{26}$ These cell kinetic experiments showed that primary cultures in vitro are bimodal mixtures of dividing and senescent cells. The proportions of which alter as the cells are serially passaged. A simplified version of the two kinetic models for cell senescence is shown in fig 1.

This behaviour and related work based on the analysis of clone sizes through the life spans of human fibroblast ${ }^{27}$ and glial cell ${ }^{28}$ cultures is consistent with a counting mechanism that
Table 1 Evidence linking senescence with aging

\begin{tabular}{|c|c|}
\hline Evidence & Reference \\
\hline $\begin{array}{l}\text { Human cell cultures show a decline in } \\
\text { growth potential with advancing donor } \\
\text { age }\end{array}$ & $11-17$ \\
\hline $\begin{array}{l}\text { The proliferative lifespan of fibroblasts in } \\
\text { culture correlates strongly with the } \\
\text { lifespan of the species from which they } \\
\text { were taken }\end{array}$ & 18 \\
\hline $\begin{array}{l}\text { Calorie restriction extends the lifespan of } \\
\text { whole organisms and leads to a reduced } \\
\text { number of senescent cells in lens } \\
\text { epithelium in vivo }\end{array}$ & 19 \\
\hline $\begin{array}{l}\text { Cultures of vascular endothelial cells } \\
\text { derived from atherosclerotic arteries } \\
\text { show a greatly reduced lifespan } \\
\text { compared to autologous cultures derived } \\
\text { from veins }\end{array}$ & 20 \\
\hline $\begin{array}{l}\text { Organ cultured corneas show a strongly } \\
\text { age linked increase in the number of } \\
\text { senescent cells in the endothelial layer }\end{array}$ & 21 \\
\hline $\begin{array}{l}\text { The pattern of gene expression in } \\
\text { senescent cells in vitro is consistent with } \\
\text { the development of age related } \\
\text { degenerative disease in vivo }\end{array}$ & 22,23 \\
\hline $\begin{array}{l}\text { The number of senescent cells observed } \\
\text { within dermal tissue sections increases in } \\
\text { a strongly age dependent manner }\end{array}$ & 24 \\
\hline $\begin{array}{l}\text { The proliferative lifespan of fibroblasts } \\
\text { from donors with progeroid syndromes is } \\
\text { significantly reduced }\end{array}$ & Present article \\
\hline
\end{tabular}

operates at each cell division. This mechanism contains within it a strong stochastic (chance) element. Essentially at each cell cycle the cell has a chance of committing to senescence or continuing to divide with the relative probability of each event dependent on the number of times the cell has divided before. ${ }^{29}{ }^{30}$ The mechanisms responsible for this process are gradually being characterised and have mostly built upon a series of cell fusion experiments which demonstrated: (1) that the phenotype of senescence was dominant over that of growth in synkaryon fusions between growing and senescent human fibroblasts ${ }^{31}$; (2) that senescence was genetically active and not the result of random damage following fusions between senescent cells derived from different cultures, ${ }^{31}$ and heterokaryon experiments between young and senescent cells, which showed

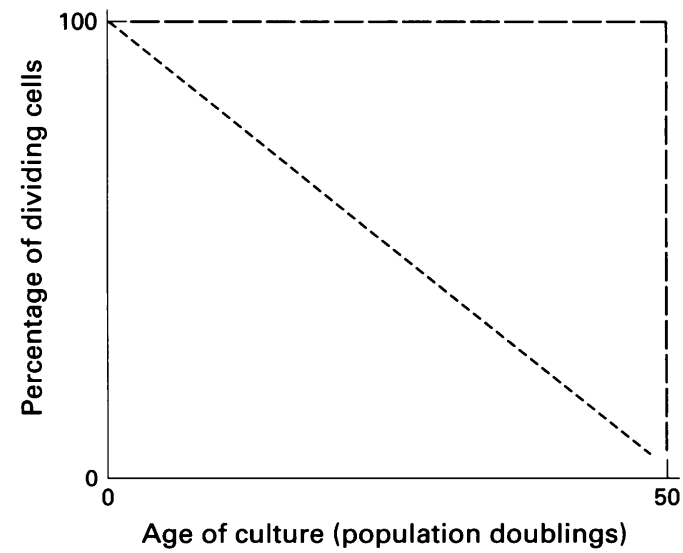

Figure 1 Simple schematic of the difference in kinetic behaviour between a unimodal (dashed line) and a bimodal (dotted line) population. A unimodal population would display a fixed fraction of dividing cells until the very last population doubling when they would enter senescence simultaneously. In contrast a bimodal population has senescent cells present from the start. Analyses of gene expression within the culture such as northern blots thus give an average for the population and can be misleading unless the fraction of dividing cells is known. 
that senescent nuclei or cytoplasm could inhibit DNA synthesis in the young nucleus ${ }^{32}$; (3) that synkaryon fusions of immortalised cells gave rise to clones that underwent senescence, and that the fusion partners in these studies could be assigned into four distinct complementation groups. ${ }^{33}$

The principal molecule involved in bringing about senescence in fibroblasts appears to be the p21 inhibitor of the cdk2-cyclin complexes. ${ }^{3}$ p21 was originally identified as a cell senescence derived inhibitor in an expression screen. ${ }^{34}$ Recently evidence has also emerged that the p16 INK4 inhibitor may also repress cdk4-cyclin D kinase activity. ${ }^{35}{ }^{36}$ Both cyclin D kinase inhibitors and their upstream regulatory genes, such as p53, are involved in a wide range of cell death and differentiation processes. ${ }^{37}$ However, cell senescence is not an apoptotic phenomenon and has recently been shown to be a distinct process from terminal differentiation. ${ }^{38}$ These molecules appear to be the effectors of cell senescence rather than the trigger, which must be sought at a higher level of cell control.

One of the most plausible systems by which cells may count their divisions to have been
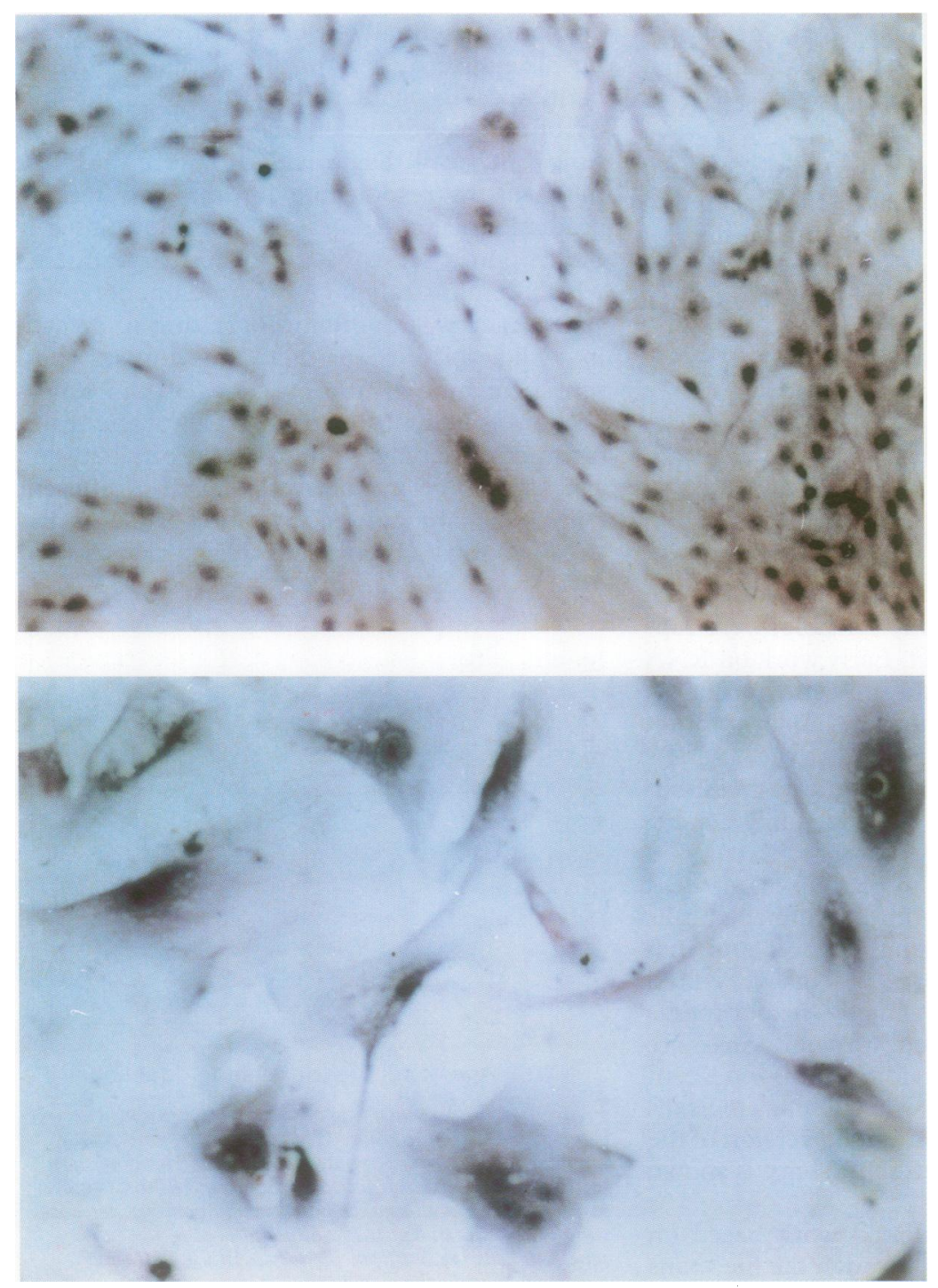

Figure 2 Haematoxylin and eosin staining of (top) young and (bottom) senescent mesothelial cells (original magnification $\times 400$ ). suggested in recent years is the progressive loss of telomeric sequences from the ends of chromosomes. In the absence of any mechanism to produce compensatory de novo synthesis of telomeric DNA, these chromosomes are faced with what has been termed the "end replicationo problem". ${ }^{39}$ This results from the inability of allo known DNA dependent DNA polymerases tơ commence synthesis de novo. At the termini region at least as large as the priming RNA primer for lagging strand DNA synthesis wille systematically be deleted every time the celle undergoes division. In contrast, in most? immortal human cell lines there appears to be compensatory de novo synthesis of telomerion DNA by the enzyme telomerase and a stable $\overrightarrow{0}$ maintenance of telomere length..$^{39-41}$

In most primary human cells telomerase is absent, and telomere shortening with prolifera $-\frac{3}{3}$ tion in vitro has been reported. ${ }^{40-43}$ This short ening is presumed to reflect losses from a fail o ure in end replication, although the problem of C strand degradation may also be shown to ${ }_{\oplus}^{\omega}$ contribute. ${ }^{44}$ An analogous decline in telomereo length with donor age has been reported for a variety of human tissues. ${ }^{40}{ }^{45}$ As the loss of telomeric DNA is linked to passage through $\delta_{0}$ phase it forms an attractive mechanism byd which cells can count divisions. However, as alL the components of the telomerase enzyme havee yet to be cloned, interventional tests of the hypothesis are not yet possible.

Why does senescence matter?

Once senescent, human cells display a varietro of characteristics that are best broadly de 0 scribed as a cessation of DNA replication under normal conditions, and an altered spec $\stackrel{3}{-}$ trum of gene expression. This is best illustrated in adherent cells where a dramatic shift in cell size usually also accompanies the onset of senescence (fig 2). It should be noted that senescence is a highly active but selective proc? ess, some genes are repressed, some genes arê upregulated, and some totally novel messages are induced. This is perhaps best illustrateo with respect to the c-fos proto-oncogener Repression of c-fos is a characteristic event in the replicative failure of $\mathrm{T}$ cells ${ }^{46}$ and fibroblasts $^{47}$ (although it does not occur iñ senescent melanocytes ${ }^{3}$ ). However, a number of other cell cycle associated genes (including c-myc and H-ras) are not repressed. ${ }^{48}$ Table ${ }^{2}$ lists a number of the principal changes identified in senescent cells. Many more have been reported. ${ }^{49}$

\section{Linking cell senescence and progeroid syndromes}

Given the contention that cell senescence is linked to the normal aging process the ability of cells from progeroid donors to grow in culture has been studied for over 30 years. These stud․ ies have principally involved the segmentat progeroid syndromes (that subset of progeroid syndromes in which multiple aspects of aging are mimicked) rather than the unimodal type (in which a single tissue or process is subjected to accelerated "aging", exemplified by Alzheimer's disease). A reduction in the ability of 
Table 2 Selected alterations in cell phenotype with the onset of senescence

\begin{tabular}{lll}
\hline Phenotypic alteration in senescence & Cell type & Reference \\
\hline Repression of c-fos & Fibroblasts, T lymphocytes & 46,47 \\
Repression of cyclin A \& B & Fibroblasts & 35 \\
G $_{2}$ arrest on restimulation without division & Fibroblasts, T lymphocytes & 50,51 \\
Elevated collagenase & Fibroblasts & 52 \\
Elevated TIMP 2 & Fibroblasts, endothelial cells & 53,54 \\
Elevated PAI-1 & Fibroblasts, endothelial cells & 54 \\
Elevated ceramide & Fibroblasts & 55 \\
Transcriptional repression of IGF-1 gene. & Fibroblasts & 56 \\
Specific induction of Ws3.10 inhibitor of Ca ${ }^{2+}$ & & 57 \\
dependent membrane currents & Fibroblasts & 58 \\
Elevated IL-1a expression & Fibroblasts & \\
Senescence associated $\beta$ galactosidase activity & Fibroblasts, keratinocytes, \\
& mammary epithelial cells, \\
endothelial cells, neonatal & 24 \\
Specific induction of SAG gene & melanocytes & 59 \\
Elevation of cytochrome b and NADH 4/4L & Fibroblasts & 60 \\
subunit & Fibroblasts & \\
\hline
\end{tabular}

fibroblasts to proliferate relative to normal controls has been reported for trisomy 21 , Rothmund-Thompson syndrome, ataxia telangiectasia, and Hutchinson-Gilford progeria. ${ }^{61-63}$ The failure of fibroblasts to grow has however been most heavily studied in Werner's syndrome where the reduction is particularly severe and the molecular basis of the disease is now especially well understood.

The principal features of Werner's syndrome are shown in table 3 and have been reviewed previously. ${ }^{64}$ The clinical changes are accompanied by a truly striking reduction in growth potential best exemplified by a study of 20 Werner's syndrome cell strains derived from three patients that demonstrated that the average population doublings of the strains were only $27 \%$ of the average population doubling obtained from 10 control strains. No overlap was observed between the population doubling of the longest lived Werner's syndrome strain and the shortest lived normal strain. ${ }^{65}$ Literature review and a range of other studies confirmed these results and showed that Werner's syndrome cell strains have a $70 \%$ reduction in their expected lifespan in culture, it was also observed that more than $90 \%$ of Werner's syndrome cell cultures fail to accomplish 20 population doubling in vitro. ${ }^{63}$

The mechanistic basis of this behaviour remained unclear until the cloning of the Werner's syndrome gene (WRN) in 1996. However, molecular cell biology studies provided two complementary pieces of data. Kinetic studies, which compared the rate of loss of the fraction of dividing cells in Werner's syndrome and normal fibroblast cultures, showed that the cause of the short culture lifespan in Werner's syndrome was a threefold to fivefold accelerated rate of exit from the cell cycle. $^{667}$ Put simply, the probability of any dividing Werner's syndrome cell entering senescence was three to five times more probable than an equivalent control fibroblast. Simultaneously it was demonstrated that both immortalised Werner's syndrome cell lines and primary cell strains displayed a "mutator phenotype", a greatly elevated mutation rate when placed under selection conditions for the emergence of HPRT[-] clonal variants. Further analysis showed that the HPRT[-] muta- tions in Werner's syndrome were characterised by extremely large DNA deletions compared with controls. ${ }^{68} 69$ This evidence suggested a loss of function mutation which gave a detectable in vitro phenotype involving DNA recombination.

A systematic attempt to clone the gene responsible for Werner's syndrome was undertaken in the late 1980 s. Initial efforts based on linkage analysis localised the disorder to chromosome $8 \mathrm{p} 12 .^{70}$ Subsequent positional cloning identified the WRN gene ${ }^{71}$ in 1996. These studies demonstrated that WRN encoded a putative protein of 1432 amino acids with a central region approximately $60 \%$ homologous to the recQ gene of Escherishia coli, the F18C5C gene of Caenorhabditis elegans, and the human RECQL gene. On this evidence, WRN is believed to encode a novel helicase. WRN is expressed fairly widely in muscle, fibroblasts, transformed B cell lines, heart, pancreas, and placenta. Neural expression was not demonstrated correlating with a lack of unusual neurological pathology in Werner's syndrome patients. ${ }^{63}$ Most recently the complete intronexon structure of WRN was determined. ${ }^{72}$ The gene has 35 exons and an unusual exon duplication within the helicase domain that appears to be a relatively recent event. WRN can essentially be broken down into three regions; a 5' region (codons 1-539) that contains the duplication and has no significant homology to any other genes (although it contains long acidic stretches similar to those seen in the XPB helicase); a central region (codons 540-963) that is highly homologous to the DExH-box DNA and RNA helicases; and a 3 ' region (codons 964-1432) with no close homology to any other gene and as yet no clear potential function. Eighty three per cent of the mutations within the Japanese Werner's syndrome population (two splice junction and two nonsense mutations) were located within this region and left the helicase domain intact. ${ }^{72}$ More recently, mutations within the helicase region have been identified. The cell strain (2Br.WS) carrying one of these mutations (a CGA $\rightarrow$ TGA nonsense at codon 889 ) was previously used in kinetic studies and gave an extremely rapid rate of senescence. ${ }^{66}$ A series of subtractive hybridisation studies have identified a number of genes in senescent Werner's syndrome cells that are also upregulated in senescent normal fibroblasts. ${ }^{73}{ }^{74}$ It thus appears that loss of function mutations within the WRN helicase can induce premature entry into senescence in fibroblasts. The presence of such senescent

Table 3 Clinical feature of Werner's syndrome

Diagnostic inclusion criteria for Werner's syndrome

Autosomal recessive inheritance

Bilateral cataracts

Dermatological pathology (tight skin or ulceration)

Short stature

Premature greying/thinning of hair

Diabetes mellitus

Hypogonadism

Osteoporosis

Mesenchymal or other rare neoplasms

Flat feet

High pitched or hoarse voice 
cells within the bodies of Werner's syndrome patients would explain many of the pathological features of the disorder, and strongly support the cell hypothesis of aging. ${ }^{75}$ However, while the identification of the defective Werner's syndrome gene is a triumph of molecular biology, there are some provocative areas of Werner's syndrome cell biology to be investigated.

\section{Why was WRN never complemented in cell fusion experiments?}

Werner's syndrome is a classic autosomal recessive mutation, and cells from obligate Werner's syndrome heterozygotes show a normal rate of exit from the cell cycle when analysed in kinetic studies, indicating that a single wild-type WRN allele is sufficient for normal function. However, cell fusion experiments between early passage young and Werner's syndrome fibroblasts failed to produce growing hybrids, instead a lifespan closer to the Werner's syndrome parent was obtained. While many of the fusions in these studies would have involved the fusion of senescent Werner's syndrome fibroblasts to growing young cells (due to the bimodal nature of the populations and the accelerated exit rate of Werner's syndrome cultures) several of the studies were conducted with Werner's syndrome cultures of such low population doubling that a high fraction of cycling cells should have been present. ${ }^{65}$ Why was WRN not complemented?

Recent patch clamp analysis of $\mathrm{Ca}^{2+}$ dependent potassium currents of individual growing Werner's syndrome and normal fibroblasts from our laboratory suggest that growing Werner's syndrome cells are not exactly the same as their normal counterparts. ${ }^{76}$ Evoked currents in the Werner's syndrome fibroblasts displayed a different reversal potential to that of the normal controls, and the cells registered a larger capacitance (size) although they were not senescent. A possible explanation for this behaviour is that mutation of WRN increases the rate at which cells enter "commitment"-a cell kinetic phase between simple growth and senescence that has been postulated but never formally demonstrated. ${ }^{77}$ Alternatively, WRN may effect some unknown characteristic that prevents simple complementation of the helicase. A failure to repress c-fos at senescence has been reported in $2 \mathrm{Br}$. WS, ${ }^{78}$ which suggests that senescence in Werner's syndrome cells may be subtly different from that in normal cells (although the presence of a transient "restimulatable" phase at senescence renders this experiment difficult to interpret ${ }^{50}$ ). A series of subtractive cloning studies carried out in senescent Werner's syndrome fibroblasts have identified genes also overexpressed in senescent normal cells, which strongly suggests that the Werner's syndrome growth arrest is essentially true cell senescence. ${ }^{57} 7^{74}$ It is thus pertinent to enquire how a helicase-type mutation may trigger cell senescence.

Does DNA damage cause senescence?

The concept that defective DNA repair is linked to the aging process is not a new idea. ${ }^{79}$
The discovery that WRN is a mutant helicase associated with a mutator phenotype potentially strengthens the association. However, defective DNA repair has not been unequivocally observed in Werner's syndrome either in studies using classic DNA repair assays such as으 unscheduled DNA synthesis ${ }^{80}$ and mutagen survival studies, ${ }^{81}$ or more sophisticated assays $\stackrel{0}{=}$ for strand specific or gene specific repair. ${ }^{82} \stackrel{\Rightarrow}{\Rightarrow}$ Similarly, cells from donors with classic DNA repair defects such as xerderma pigmentosum?

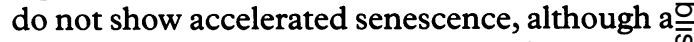
mutator phenotype is present in at least some? complementation groups. ${ }^{83}$ Instead a defective 2 ability to repair ultraviolet damage products isis present. Cockayne's syndrome, a highly placed $\vec{\circ}$ candidate for a segmental progeroid syndrome, $\overrightarrow{-}$ has three distinct complementation groups, $\vec{\omega}$ one of which (group B) is due to a defective helicase (ERCC6). ${ }^{84}$ In this syndrome excision? repair of ultraviolet damage is essentiallyo normal but the cells show a failure of RNA synthesis recovery following ultravioletw exposure. ${ }^{85}$ To complicate matters furthero overlapping xerderma pigmentosum and Cockayne's syndrome phenotypes exist ${ }^{86}$; ando while some Cockayne's syndrome fibroblasto strains show a slightly reduced lifespan in vitro the number of population doublings achieved $ᄃ$ are very close to the normal range, unlike Werner's syndrome in which there is no overlap. Similarly some ataxia telangiectasia fibroblasts demonstrate a reduced lifespan in culture but the syndrome has at least nine rec-0 ognisable complementation groups rendering analysis complex. Cells from trichothiodystro phy, a disorder with two complementation $\vec{B}$ groups one of which shows DNA repair defects, has never been reported to show accel erated cell senescence. ${ }^{84}$ Hutchinson-Gilford. progeria, perhaps the best known of alB progeroid syndromes, is associated with severely reduced fibroblast growth in vitro; how? ever, its DNA repair features are variable which suggests that different complementation groups may also exist within the disease. ${ }^{61}$ It is clear that any relation between aging and DNAD damage will not be a simple affair and will require rigorous study to validate.

\section{Is senescence the result of altered} telomere metabolism?

Do any of these premature aging syndromes? shed light on the normal process of aging, and in particular do any critically address th normal mechanism leading to replicative se $=$ nescence? One of the more plausible models for the trigger to replicative senescence is tha吕 progressive telomere shortening in somatio cells that do not express telomerase eventually leads to one or more critically short telomeres which in some way signals cell cycle arrest an\& senescence. ${ }^{41-46}$ In human fibroblasts divisiol potential in culture correlates well with initias telomere length both for bulk cultures from different individuals ${ }^{88}$ and for subclones derived from the same culture. ${ }^{89}$ Telomere loss in fibroblasts only occurs when the cells are dividing and not when held quiescent by density dependent contact inhibition. ${ }^{90}$ 


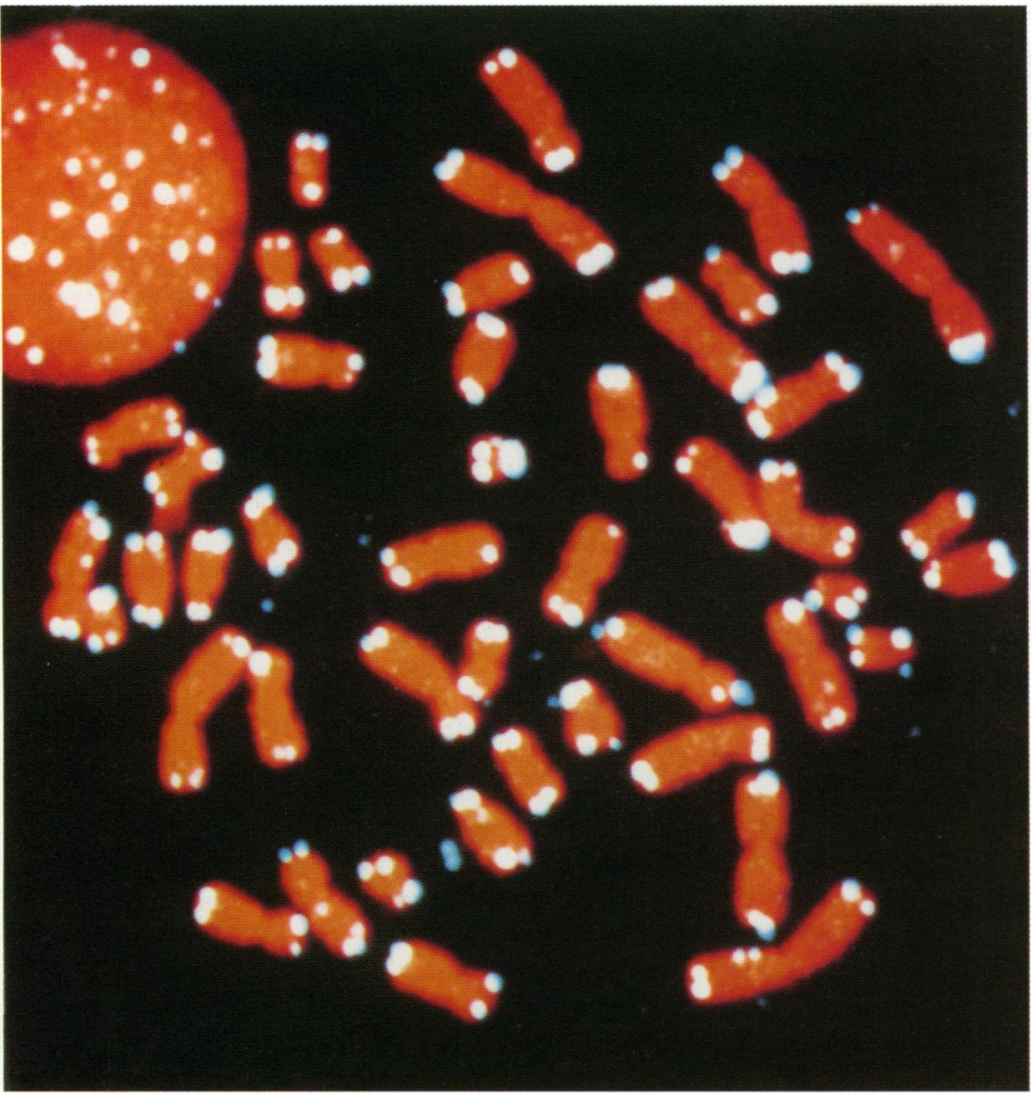

Figure 3 Human metaphase chromosomes (red) and their telomeres detected by in situ hybridisation with a (TTAGGG)n probe (yellow). (Reprinted from reference 39 with permission of Oxford University Press.)

However, human fibroblasts will also enter a senescent-like state within a few days of infection with a retroviral vector expressing activated (V12) H-ras. ${ }^{91}$ This raises the possibility that senescence can be induced by aberrant mitogenic pathway stimulation, and that replicative lifespan represents a response to chronic mitogen load. ${ }^{91}$ It is difficult experimentally to separate mitogenic stimulation from cell division, and one might argue that the fact that quiescent cells do not undergo senescence is related more to their lack of exposure to mitogenic stimulation; in this example ${ }^{91}$ suppression by contact inhibition. This would open the way for mutations that affect cell cycle progression but leave the mitogen stimulation pathway intact to increase the rate of senescence as measured on a per cell division basis. In this respect it is interesting to note that one pleiotropic effect of the WRN mutation is increased cell cycle time. ${ }^{92}$

Telomere dynamics have been measured for a number of progeroid syndromes. For both ataxia telangiectasia ${ }^{93}$ and Hutchinson-Gilford progeria, ${ }^{88}$ telomeres are shorter than for age matched normal controls, but in neither case have data on the per cell division rate of telomere shortening been presented. Although altered telomere dynamics cannot be ruled out, it is also possible that the increased telomere loss rates act simply as a biomarker for increased cellular turnover in these cases.

More data are available for Werner's syndrome, where cultured fibroblasts show an increased rate of telomere loss. ${ }^{92}$ However, they senesce at a point where their telomeres are considerably longer than would normally be expected for a senescent fibroblast. ${ }^{89}$ Schulz et al argue that this is not compatible with a simple telomere driven senescence in these cells. ${ }^{92}$ However, a number of points need to be addressed before altered telomere dynamics can be fully excluded as the underlying cause of the premature senescence of Werner's syndrome cells. First, although the amount of telomeric DNA at senescence is longer than in normal senescent fibroblasts, it is possible that the length at which a telomere is recognised as critically short is different in Werner's syndrome cells. The ability of the cell to recognise a normal chromosome end as a telomere rather than a double strand DNA break, reflects not simply the terminal DNA sequences (fig 3) but also the altered chromatin structure at the natural end caused by various telomere binding proteins. A helicase such as WRN could have pleiotropic effects on the assembly and maintenance of the terminal chromatin structure, leading to compromised telomere behaviour and it signalling as critically short at an increased telomere length. Indeed, compromised terminal chromatin structure is one of a number of explanations for why histone deacetylase inhibitors cause a dramatic decrease in proliferative lifespan without apparently altering the rate of telomere loss. ${ }^{94}$

Another caveat regarding the data on telomere loss rates in Werner's syndrome cells is that the hypothesised most important biological variable is not the average telomere length, but rather that of the shortest telomere in the nucleus. It is possible, therefore, that the distribution of telomere lengths might be altered in Werner's syndrome cells (because of alterations in telomere metabolism), leading to a situation where bulk telomere length is somewhat larger than normal when the first critically short telomere arises. This is a possibility that requires further attention as there clearly is some form of alteration in telomere dynamics in Werner's syndrome cells (the rate of loss is greater than in normal cells).

How might this arise? It seems at first paradoxical that telomere loss rates could vary between cells that express no detectable telomerase activity. Certainly there will be a basal level of telomere loss because of the end replication problem, but there is increasing data for an additional route to telomere shortening involving degradation of the C-strand of the telomere, the strand complementary to that synthesised by telomerase. This stems from studies in budding yeast where certain cdc13 and $\operatorname{stn} 1$ alleles on the appropriate genetic background led to the accumulation of extensive regions of single stranded DNA extending from the end of the chromosome, reflecting degradation of the C-strand in a cell cycle controlled fashion. ${ }^{44}{ }^{95-98}$ Mutations in RAD24 can suppress this phenotype-of interest as the product of this gene regulates the activity of RAD17, an exonuclease whose known directionality $(3 \rightarrow 5)$ is just that necessary to produce C-strand degradation from the telomere. ${ }^{99}$ This model illustrates the potential to modulate telomere loss rates independent of 
telomerase. Although mammalian homologues of CDC13 and others have yet to be identified, a structural analysis of human telomeres is consistent with the existence of a C-strand degradation pathway in human cells. ${ }^{100}$ It is interesting to note that human fibroblasts grown in $40 \%$ partial pressure of oxygen show a marked increase in both the rate of senescence and of telomere loss, together with an accumulation of single stranded DNA at the telomeres. ${ }^{101}$ Although consistent with the available data, whether hyperoxia exerts its effects by modulating C-strand degradation remains to be determined.

The mechanism whereby senescence is activated in Werner's syndrome cells remains a mystery. The altered telomere dynamics ${ }^{92}$ suggest some altered behaviour in these regions, but whether this is causal in the premature senescent phenotype, or whether it is simply a side effect of a mutation potentially capable of modulating DNA and chromatin structure, is far from clear. It is important to note that the mechanism whereby senescence is activated in Werner's syndrome cells is not necessarily the same as that normally used by fibroblasts at the end of their lifespan, as the cell senescence hypothesis of aging is concerned with the occurrence and phenotype of senescent cells rather than the details of the mechanism that led to them arising. Indeed, the ability of $\mathrm{H}$-rasV12, hyperoxia, and histone deactelyase inhibitors ${ }^{9194101}$ all to trigger apparently indistinguishable states of cellular senescence seems to indicate that multiple effectors can lead to the same final outcome. With so many potential triggers there is ample room for genetic lesions such as WRN to lead to senescent cells by activating an alternative route, as opposed to modulating the normal effector route to senescence. Perhaps the characterisation of other progeroid syndromes to the level of detail now available for Werner's syndrome will shed additional light on the control of these processes and ultimately on aging itself.

1 Technology foresight panel on health and life sciences. Progress through partnership Technology Foresight 4 . Lon don: HMSO, 1995:20-2.

2 Kirkwood TBL, Holliday R. Evolution of ageing and longevity. Proc R Soc Lond B Biol Sci 1979;205:531-46.

3 Smith JR, Periera-Smith OM. Replicative senescence: implications for in vitro aging and tumor supression. implications for in vitro

4 Martin GM. Genetics and ageing: the Werner syndrome as a segmental progeroid syndrome. Adv Exp Biol Med 1985 190:161-71.

Kirkwood TBL. Human senescence. Bioessays 1996;18: 1009-16.

6 Leckie BJ. High blood pressure: hunting the genes. Bioessays 1993;14:37-41.

7 Carrel A. Artificial activation of the growth in vitro of connective tissue. $\mathcal{F} \operatorname{Exp}$ Med 1913;16:14-19.

8 Hayflick L, Moorehead PS. The serial cultivation of human diploid fibroblast cell strains. Exp Cell Res 1961;25:585621.

9 Hayflick $\mathrm{L}$. The limited in vitro lifespan of human diploid cell strains. Exp Cell Res 1965;37:614-36.

10 Hayflick L. The cell biology of aging. $\mathcal{F}$ Invest Dermatol 1979;73:8-14.

11 Martin GM, Sprague CA, Epstein CJ. Replicative lifespan of cultivated human cells. Effects of donor's age, tissue and genotype. Lab Invest 1970;23:86-92.

12 Schneider EL, Mitsui Y. The relationship between in vitro cellular aging and in vivo human age. Proc Natl Acad Sci 1976;73:3584-8.

13 Bermach G, Mayer U, Naumann GOH. Human lens epithelial cells in culture. Exp Eye Res 1991;52:113-19.

$14 \mathrm{Lipman} R \mathrm{D}$, Taylor A. The in vitro replicative potential and cellular morphology of human lens epithelial cells derived from different aged donors. Curr Eye Res 1987;6:1453-7.
15 Blake DA, Yu H, Young DL, Caldwell DR. Matrix stimulates the proliferation of human corneal endothelial cells in culture. Invest Ophthmol Vis Sci 1997;38:1119-29.

16 Perillo NL, Walford RL, Newman MA, Effros, RB. Human $T$ lymphocytes posess a limited in vitro lifespan. Exp Gerontol 1987;24:177-8.

17 Gilchrest BA. Relationship between actinic damage and chronologic aging in keratinocyte cultures in human skin. $\mathcal{F} \underset{\mathrm{O}}{\widehat{\mathrm{O}}}$ Invest Dermatol 1983;81:184S-9S

18 Rohme D. Evidence for a relationship between longevity of $T$ mammalian species and life spans of normal fibroblasts in vitro and erythrocytes in vivo. Proc Natl Acad Sci 1981;78: 5009-13.

$19 \mathrm{Li} \mathrm{Y,} \mathrm{Yan} \mathrm{Q,} \mathrm{Wolf} \mathrm{NS.} \mathrm{Long-term} \mathrm{calorie} \mathrm{restriction} \mathrm{delays} \overrightarrow{\bar{\omega}}$ age-related decline in proliferation capacity of murine lens epithelial cells in vitro and in vivo. Invest Ophthmol Vis Sci 1997;38:100-8.

20 Van Hinsburgh VWM. Arteriosclerosis: impairment of $\overline{\bar{c}}$ cellular interactions in the arterial wall. Ann NY Acad Sci $\vec{\nabla}$ 1992;673:321-30.

21 Hoppenreijs VPT, Pels E, Vrensen GFJM, Treffers WF. @ Effects of platelet derived growth factor on endothelial wound healing of human corneas. Invest Ophthmol Vis Sci $\vec{O}$ 1994;35:150-61.

22 Linskens MHK, Feng J, Andrews WH, Enlow BE, Shahin MS, Tonkin LA, et al. Cataloging altered gene expression in $\omega$ young and senescent cells using enhanced differential young and senescent cells using enhan
display. Nucleic Acid Res 1995;23:3244-51.

23 Gray MD, Norwood TH. Cellular aging in vitro. Rev Clin Gerontol 1995;5:369-81.

24 Dimri G, Lee X, Basile G, Acosta M, Scott G, Roskelly C, et ir al. A biomarker that identifies senescent human cells in culture and in aging skin in vivo. Proc Natl Acad Sci 1995; $\omega$ 92:9362-7.

25 Maciera-Coelho A, Ponten J, Philipson L. The division cycle and RNA synthesis in diploid human cells at different passage levels in vitro. Exp Cell Res 1966;42:673-684.

26 Cristofalo VJ, Scharf BB. Cellular senescence and DNA synthesis. Exp Cell Res 1973;76:419-27.

27 Smith JR, Whitney RG. Intraclonal variation in proliferative potential of human diploid fibroblasts: stochastic mech- $\underset{-}{ }$ anism for cellular ageing. Science 1980;207:82-4.

28 Ponten J, Stein WD, Shall S. A quantitative analysis of the ageing of human glial cells in culture. $f$ Cell Physiol 1983;117:342-52.

29 Shall S, Stein WD. A mortalisation theory for the control of cell proliferation and for the origin of immortal cell lines. 7 Theoret Biol 1979;76:219-31.

30 Shall S. Mortalisation or reproductive sterility of animal $\bar{\partial}$ cells in culture. In: Potten CS, ed. Perspectives on mammalian cell death. Oxford: Oxford University Press, $\frac{\circ}{\mathbb{Q}}$ mammalian cell

31 Littlefield JW. Attempted hydridisations with senescent human fibroblasts. F Cell Physiol 1973;82:129-32.

32 Norwood TH, Smith JR, Stein GH. Aging at the cellular level: the human fibroblast-like cell model. In: Schneider EL, Rowe JW, eds. Handbook of the biology of aging. San Diego: Academic Press Inc, 1990:131-54.

33 Smith JR, Periera-Smith OM. Genetic and molecular studies of cellular immortalisation. Adv Cancer Res 1990;54:6377.

34 Noda A, Ning Y, Venable SF, Periera-Smith OM, Smith JR. Cloning of senescent cell derived inhibitors of DNA synthesis using an expression screen. Exp Cell Res 1994;211:90-8.

35 Stein GH, Dulic V. Origins of $\mathrm{G}_{1}$ arrest in senescent human fibroblasts. Bioessays 1995;17:537-43.

36 Campisi J. The biology of replicative senescence. Eur $\mathcal{F}$ Cancer 1997;33:703-10.

37 Gao CY, Zelenka PS. Cyclins, cyclin dependent kinases and differentiation. Bioessays 1997;19:207-315.

38 Norsgaard H, Clark BFC, Rattan SIS. Distinction between o differentiation and senescence and the abscence of $\mathrm{N}$ increased apoptosis in human keratinocytes undergoing cellular ageing in vitro. Exp Gerontol 1996;31:655-68.

39 Kipling D. The telomere. Oxford: Oxford University Press, 1995.

40 de Lange $T$. Telomere dynamics and genome instability in 0 human cancer. In: Blackburn EH, Greider CW, eds. Telomeres New York: Cold Spring Harbor Press, 1995:265-93.

41 Harley CB, Villeponteau B. Telomeres and telomerase in aging and cancer. Curr Opin Genet Dev 1995;5:249-55.

42 Harley CB, Futcher AB, Greider CW. Telomeres shorten $O$ during ageing of human fibroblasts. Nature 1990;345:45860.

43 Henderson S, Allsopp R, Spector D, Wang SS, Harley C. In $\mathbb{D}$ situ analysis of changes in telomere size during replicative aging and cell transformation. $\mathcal{F}$ Cell Biol 1996;134:1-12.

$44 \mathrm{Lin} \mathrm{JJ,} \mathrm{Zakian} \mathrm{VA.} \mathrm{The} \mathrm{Saccharomyces} \mathrm{CDC13} \mathrm{protein} \mathrm{is} \mathrm{a}$ single-stranded TG $_{1-3}$ telomeric DNA-binding protein in vitro that affects telomere behavior in vivo. Proc Natl Acad Sci USA 1996;93:13760-5.

45 Hastie ND, Dempster M, Dunlop MG, Thompson AM, $\frac{\bar{Q}}{\partial}$ Green DK, Allshire RC. Telomere reduction in human? colorectal carcinoma and with ageing. Nature 1990;346: 866-8.

46 Sikora E, Kaminska B, Radziszewska E, Kaczmarek L. Loss of transcription factor AP1 DNA binding activity during lymphocyte aging in vivo. FEBS Lett 1992;312:179-82.

47 Sheshadri T, Campisi J. Repression of c-fos and an altered genetic programme in senescent human fibroblasts. Science 1990;247:205-9. 
48 Rittling SR, Brooks KM, Cristofalo VJ, Baserga R. Expression of cell cycle dependent genes in young and senescen WI38 fibroblasts. Proc Natl Acad Sci USA 1986;83:331620.

49 Hubbard K, Ozer HL. Senescence and immortalisation of human cells. In: Studzinski, GP, ed. Cell growth and apoptosis: a practical approach. Oxford: IRL Press, 1995: apoptosis: $229-49$.

50 Kill IR, Shall S. Senescent human diploid fibroblasts are able to support DNA synthesis and to express markers able to support DNA synthesis and to express mark

51 Perillo NL, Naeim F, Walford RL, Effros RB. In vitro aging in T lymphocyte cultures: analysis of DNA content and cell size. Exp Cell Res 1993;207:131-5.

52 Millis AJT, Sottile J, Hoyle M, Mann DM, Diemer V. Collagenase production by early and late passage cultures of human fibroblasts. Exp Gerontol 1989;24:559-75.

53 Zeng G, Millis AJ. Expression of $72 \mathrm{Kd}$ gelatinase and TIMP2 in early and late passage human fibroblasts. Exp Cell Res 1994;213:148-55.

54 West MD, Shay JW, Wright WE, Linskens MHK. Altered expression of plasminogen activator and plasminogen act ivator inhibitor during cellular senescence. Exp Gerontol 1996;31:175-93.

55 Venable ME, Lee JY, Smyth MJ, Bielawska A, Obeid LM. Role of ceramide in cell senescence. $\mathcal{F}$ Biol Chem 1995;270 30701-8

56 Ferber A, Chang CD, Sell C, Ptasznik A, Cristofalo VJ, Hubbard $\mathrm{K}$, et al. Failure of senescent human fibroblasts to express the insulin-like growth factor 1 gene. $\mathrm{f} \mathrm{Biol} \mathrm{Chem}$ 1993;268:17883-8.

57 Liu S, Thweatt R, Lumpkin CK, Goldstein S. Supression of calcium dependent membrane currents in human fibroblasts by replicative senescence and forced expression of a gene sequence encoding a putative calcium-binding protein. Proc Natl Acad Sci USA 1994;91:2186-90.

58 Zeng G, Millis AJT. Differential regulation of collagenase and stromelysin mRNA in late passage cultures of human fibroblasts. Exp Cell Res 1996;222:150-6.

59 Wistrom C, Villeponteau B. Cloning and expressionof SAG a novel marker of cellular senescence. Exp Cell Res 1992;199:355-62.

60 Kodama S, Yamada H, Annab L, Barrett JC. Elevated expression of mitochondrial cytochrome $b$ and NADH expression of mitochondrial cytochrome $b$ and NADH dehydrogenase subunit $4 / 4$

61 Brown WT, Zebrower M, Kieras F. Progeria: a mode disease for the study of accelerated ageing. Basic Life Sci 1984;35:375-96.

62 Weirich-Schwaiger H, Weirich HG, Gruber B, Schweiger, M, Hirsch-Kaufmann M. Correlation between senescence and DNA repair in cells from young and old individuals and in premature aging syndromes. Mutat Res 1994;31:3748 .

63 Tollefsbol TO, Cohen HJ. Werner's syndrome: An underdiagnosed condition resembling premature aging. $A g e$ 1984;7:75-88.

64 Herd RM, Faragher RGA, Shall S, Hunter JAA. Werner's syndrome: a review of the clinical and pathological features and pathogenesis. Eur $\mathcal{F}$ Dermatol 1993;3:425-32.

65 Salk D, Bryant E, Au K, Hoehn H, Martin GM. Systematic growth studies, cocultivation and cell hybridisation studie of Werner syndrome cultured skin fibroblasts. Hum Genet 1981;58:310-16.

66 Faragher RGA, Kill IR, Tannock TCA, Hunter JAA, Shall $S$. Is the Werner's syndrome gene a "clock" gene which counts cell division? Proc Natl Acad Sci 1993;90:12030-34.

67 Kill IR, Faragher RGA, Lawrence K, Shall S. The expression of proliferation-dependent antigens during the lifespan of normal and progeroid human fibroblasts in culture. $\mathcal{F}$ Cell Sci 1994;107:571-9.

68 Fukuchi K, Tanaka K, Kumahara Y, Maramo K, Pride M, Martin GM, et al. Increased frequency of 6-thioguanine resistant peripheral blood lymphocytes in Werner syndrome patients. Hum Genet 1990;84:249-52.

69 Fukuchi K, Martin GM, Monnat RJ. Mutator phenotype of Werner syndrome is characterised by extensive deletions. Proc Natl Acad Sci USA 1989;86:5893-7.

70 Goto M, Rubenstein M, Weber J, Woods K, Drayna D. Genetic linkage of Werner's syndrome to five markers on Genetic linkage of Werner's syndrome

71 Yu CE, Oshima J, Ying-Hui F, Wijsman EM, Hisami F Alisch $\mathrm{R}$, et al. Positional cloning of the Werner's syndrome gene. Science 1996;272:258-62.

72 Yu CE, Oshima J, Wijsman EM, Nakura J, Miki T, Piussan $\mathrm{C}$, et al. Mutations in the consensus helicase domains of the Werner syndrome gene. Am ₹ Hum Genet 1997;60:330-41.

73 Lecka-Czernik B, Moerman EJ, Jones RA, Goldstein S Identification of gene sequences overexpressed in senescent
and Werner syndrome human fibroblasts. Exp Gerontol and Werner syndry

74 Murano S, Thweatt R, Schmookler-Reis RJ, Jones RA, Moerman EJ, Goldstein S. Diverse gene sequences are overexpressed in Werner syndrome fibroblasts undergoing premature replicative senescence. Mol Cell Biol 1991;11: 3905-14.
75 Thweatt $R$, Goldstein $S$. Werner syndrome and biological ageing: a molecular genetic hypothesis. Bioessays 1993;15: 421-6.

76 Faragher RGA, Hardy S, Dropcova S, Allen MC. Cycling Werner's syndrome fibroblasts display calcium dependent potassium currents. Exp Cell Res 1997;231:119-22.

77 Prothero J, Gallant JA. A model of clonal attenuation. Proc Natl Acad Sci USA 1981;78:333-7.

78 Oshima J, Campisi J, Tannock CA, Martin GM. Regulation of $c$-fos in senescing Werner syndrome fibroblasts differs from that seen in senescing fibroblasts from normal donors. f Cell Physiol 1995;162:277-83.

79 Hart RW, Setow RB. Correlation between deoxyribonucleic acid excision repair and life-span in a number of mammalian species. Proc Natl Acad Sci USA 1974;71:2169-73.

80 Higashikawa T, Fujiwara Y. Normal level of unscheduled DNA synthesis in Werner's syndrome fibroblasts in culture. Exp Cell Res 1978;113:438-41.

81 Gebhart E, Baur R, Raub U, Schinzel M, Ruprecht KW, Jonas JB. Spontaneous and induced chromosomal instability in Werner's syndrome. Hum Genet 1988;80:135-9.

82 Webb DK, Evans MK, Bohr VA. DNA repair fine structure in Werner's syndrome cell lines. Exp Cell Res 1996;224 $272-8$.

83 Norris PG, Limb A, Hamblin AS, Lehmann AR, Arlett CF Cole J, et al. Immune function, mutant frequency and cancer risk in the DNA repair defective genodermatoses xeroderma pigmentosum, cockaynes syndrome and trichthiodystrophy. F Invest Dermatol 1990;94:94-9.

84 Epstein CJ, Motulsky AG. Werner's syndrome: entering the helicase era. Bioessays 1996;18:1025-7.

85 Mayne LV, Lehmann AR. Failure of RNA synthesis to recover after UV irradiation: an early defect in cells from individuals with Cockayne's syndrome and xeroderma pigmentosum. Cancer Res 1982;42:1473-8.

86 Greenhaw GA, Hebert A, Duke-Woodside ME, Butler IJ, Hecht JT, Cleaver JE, et al. Xeroderma pigmentosum and Cockayne syndrome: overlapping clinical and biochemical phenotypes. Am f Hum Genet 1992;50:677-89.

87 Llerena JC, Murer-Orlando. Bloom syndrome and Ataxia telangiectasia. Semin Hematol 1991;28:95-103.

88 Allsopp RC, Vaziri H, Patterson C, Goldstein S, Youngla $\mathrm{EV}$, Futcher $\mathrm{AB}$, et al. Telomere length predicts replicative capacity of human fibroblasts. Proc Natl Acad Sci USA 1992;89:10114-18.

89 Allsopp RC, Harley CB. Evidence for a critical telomere length in senescent human fibroblasts. Exp Cell Res 1995;219:130-6.

90 Allsopp RC, Chang E, Kashefi-Aazam M, Rogaev EI, Piatyszek MA, Shay JW, et al. Telomere shortening is associated with cell division in vitro and in vivo. Exp Cell Res 1995;220:194-200.

91 Serrano M, Lin AW, McCurrach ME, Beach D, Lowe SW. Oncogenic ras provokes premature cell senescence associated with accumulation of p53 and pl6INK4a. Cell 1997;88:593-602.

92 Schulz VP, Zakian VA, Ogburn CE, McKay J, Jarzebowicz AA, Edland SD, et al. Accelerated loss of telomeric repeats may not explain accelerated replicative decline of Werner syndrome cells. Hum Genet 1996;97:750-4.

93 Metcalfe JA, Parkhill J, Campbell L, Stacey M, Biggs P, Byrd PJ, et al. Accelerated telomere shortening in ataxia telangiectasia. Nature Genet 1996;13:350-3.

94 Ogryzko VV, Hirai TH, Russanova VR, Barbie DA, Howard $\mathrm{BH}$. Human fibroblast commitment to a senescence-like state in response to histone deacetylase inhibitors is cell cycle dependent. Mol Cell Biol 1996;16:5210-18.

95 Wellinger RJ, Ethier K, Labrecque P, Zakian VA. Evidence for a new step in telomere maintenance. Cell 1996;85:423-33.

96 Garvik B, Carson M, Hartwell L. Single-stranded DNA arising at telomeres in cdc13 mutants may constitute a spe-
cific signal for the RAD9 checkpoint. Mol Cell Biol cific signal for the

97 Grandin N, Reed SI, Charbonneau M. Stn1, a new Saccharomyces cerevisiae protein, is implicated in telomere size regulation in association with Cdc13. Genes Dev 1997;11: 512-27.

98 Nugent CI, Hughes TR, Lue NF, Lundblad V. Cdc13p: a single-strand telomeric DNA-binding protein with a dual role in yeast telomere maintenance. Science 1996;274:24952.

99 Lydall D, Weinert T. Yeast checkpoint genes in DNA damage processing: implications for repair and arrest. Science 1995;270:1488-91.

100 Makarov VL, Hirose Y, Langmore JP. Long G tails at both ends of human chromosomes suggest a $C$ strand degradation mechanism for telomere shortening. Cell 1997;88 657-66.

101 von Zglinicki T, Saretzki G, Döcke W, Lotze C. Mild hyperoxia shortens telomeres and inhibits proliferation of fibroblasts: a model for senescence? Exp Cell Res 1995;220: 186-93. 